DOI: 10.17707/AgricultForest.65.1.21

\author{
Željko LAKIĆ, \\ Dejan SOKOLOVIĆ, Igor ĐUR円IĆ ${ }^{1}$
}

\title{
EXAMINATION OF EARLINESS OF AUTOCHTHONOUS POPULATIONS OF PERENNIAL RYEGRASS
}

\begin{abstract}
SUMMARY
Monitoring of changes in phenological phases of autochthonous populations of perennial ryegrass was conducted on the experimental field of the Agricultural Institute of Republic of Srpska in Banja Luka (Bosnia and Herzegovina) during 2007, 2008 and 2009. Seven autochthonous populations collected in Bosnia and Herzegovina $(\mathrm{BiH})$ and one variety of perennial ryegrass were used for this research. This research included the following populations of perennial ryegrass: Dragočaj, Kosjerovo, Laminci, TAS, Kupres, Maglajani, Manjača and variety Maya.

The aim of this research was to select populations of perennial ryegrass in the conditions of opened pollination on the basis of phenological observations. These genotypes should be selected on the basis of earliness, length of vegetation and other characteristics important for understanding the initial genetic materials included in the breeding program of forage crops.

During the research, the following changes were observed in phenological phases with the perennial ryegrass: growth of generative shoots $10 \mathrm{~cm}$ above the ground, the length of the vegetative phase from April 1, the period from heading to start of blossoming, duration of blossoming, and the length of the growing season. Phenological phases were observed individually by recording the date of their beginning and/or ending, and duration of the phases was expressed in number of days.

On the basis of the duration of particular phenological phases, the differences were observed among autochthonous populations of perennial ryegrass in duration of vegetation period until appearance of spiking. The earliest ear formation was determined in population Laminci with the average duration of vegetative period of 29 days. Population Manjača had the longest period until the ear formation, which lasted for 44.9 days. During these tests of the duration of the vegetation period, three groups were distinguished. The first group, characterized with a shorter vegetation period, included populations: Laminci (82.5 days), Maglajani (84 days) and Kupres (84.3 days). The second group with
\end{abstract}

\footnotetext{
${ }^{1}$ Željko Lakić, Faculty of Agriculture, University of Banja Luka, BOSNIA AND HERZEGOVINA; Dejan Sokolović, Institute for fodder crops, Kruševac, SERBIA; Igor Đurđić (corresponding author: i_djurdjic@yahoo.com), Faculty of Agriculture, University of East Sarajevo, BOSNIA AND HERZEGOVINA

Notes: The authors declare that they have no conflicts of interest. Authorship Form signed online.
} 
the vegetation ${ }^{2}$ period from 87 - 89 days included populations: TAS, Kosjerovo and the variety Maya. The latest maturing group included populations: Dragočaj and Manjača with the average duration of vegetation period of 95 days.

Keywords: perennial ryegrass, populations, phenological phases, earliness, vegetation period.

\section{INTRODUCTION}

Phenological phases represent maturity stages or segments of plant development, and occur as a result of massive physiological and biochemical processes happening during plant growth. Investigation of phenology and maturity at perennial ryegrass is very important in the begenning of breeding, since in that way we can determine approximate date of beginning of tillering and flowering and duration of these phases.

Perennial ryegrass (Lolium perenne L.) is one of the most important and commonly grown perennial fodder grasses in northern temperate climate of the world. It is especially widespread in northwest Europe, New Zealand, Australia, South Africa and South America (Yamada, 2013). One of the main prerequisite in breeding is characterisation and evaluation of the starting germplasm. According to Sokolovic et al. (2011) autochthonous populations and local ecotypes very often represented starting material in breeding programs because of their adaptation to local agro-ecological conditions. However, breeders usually do not have enough data about variability of the most important traits of autochthonous populations.

Date of heading of perennial ryegrass is very important trait affecting biomass production (Surault et al., 2009) as well as forage quality and digestibility. It has been determined that early flowering in perennial ryegrass is connected with increasing of dry matter and seed yield. Genotypes of perennial ryegrass may differ in time of heading significantly and based to this property many varieties, differing in maturity up to a month, have been created (Jung et al., 1996; Grogan and Gilliland, 2011), which allows significant mixtures and grassland managing flexibility.

Time of heading of European populations ranged in interval of 30 to 70 days after April $1^{\text {st }}$ (Charmet and Balfourier, 1994), and in certain climate conditions it can be even longer. Autochthonous material of perennial ryegrass collected from, to a certain extent, narrow area (Serbia) may also have high amount of variability for heading date (Sokolovic et al., 2006).

In collected populations of perennial ryegrass there is a great genetic variability in relation to adaptability towards different agro-ecological conditions and it is reflected in the duration of vegetation, capability and speed of regeneration, earliness or late maturing, and other important properties. Lakic et al. (2015) have estimated interaction genotype $x$ environment for the most important trait of eight autochthonous populations of perennial ryegrass by using 
AMMI method. For all tested properties, they determined additive (genotype, environment) and non-additive (interaction of genotype $x$ environment) variations. On the bases of results, the genotypes with the best stability for all tested traits were selected.

The goal of this research was to analyse phenology of perennial ryegrass autochthonous populations and to define material that differ in earliness, vegetation duration and other traits important for forage breeding programs.

\section{MATERIAL AND METHODS}

Monitoring and evaluation of phenological phases of autochthonous populations of perennial ryegrass were conducted at the experimental field of Agricultural Institute of Republic of Srpska in Banja Luka during three-year period (2007-2009). The trial was established on the valley-brown soil (clayloam soil in mechanical composition) on alluvial substratum of river Vrbas. Soil had neutral chemical reaction ( $\mathrm{pH} \mathrm{H}_{2} \mathrm{O}-7.03$ ) and contained $3.25 \%$ of humus, $15.52 \mathrm{mg} / 100 \mathrm{~g}$ of phosphorous and $35.56 \mathrm{mg} / 100 \mathrm{~g}$ of potassium.

This field research included 7 autochthonous populations of perennial ryegrass collected in $\mathrm{BiH}$ (Dragočaj, Kosjerovo, Laminci, TAS, Kupres, Maglajani, Manjača) and cultivar Maya as a standard (Poland, 1987). Populations were sowed on the field in the autumn 2006, as spaced plants $(70 \times 70 \mathrm{~cm})$ with 50 plants (five rows, 10 plants per row) representing each population.

In this trial five phenological traits of perennial ryegrass were observed (Tab. 1) and expressed as number of days from April $1^{\text {st }}$. Phenological phases were evaluated individually on each plant and expressed as population average.

Table 1. Evaluated traits in collection of perennial ryegrass populations

\begin{tabular}{|l|l|}
\hline Traits & Abbreviation \\
\hline $\begin{array}{l}\text { A moment when generative shoots reached } 10 \mathrm{~cm} \\
\text { in height }\end{array}$ & GRGS \\
\hline Duration of vegetative phase & VEGF, \\
\hline Interval heading - beginning of flowering & IHF \\
\hline Duration of flowering & FLOW \\
\hline Duration of vegetation period & VEG \\
\hline
\end{tabular}

Obtained results have been processed with ANOVA and statistical significance of differences was determined with LSD-test. Components of variance, genetic $\left(\sigma_{\mathrm{g}}^{2}\right)$, phenotypic $\left(\sigma_{\mathrm{f}}^{2}\right)$, variance of interaction $\left(\sigma_{\mathrm{g}}^{2} / \sigma_{\mathrm{y}}^{2}\right)$ and heritability in broad sense $\left(h^{2}=\sigma^{2}{ }_{g} / \sigma^{2}\right)$ were calculated, as well as . coeficient of correlation ( $r$ ) between examined phenological phases. Hierarchical cluster analysis of populations based on all traits was done by Ward method and Euclidean distances.

\section{Meteorological conditions}

The data used for temperature and precipitation were obtained from Hydro meteorological station Banja Luka (Table 2). 
Winter period in all three years of examination was warmer in relation to many-year average. Average year air temperature for the period 1961-2004 was $10.9^{\circ} \mathrm{C}$. In comparison to many-year data, average air temperatures in 2007 and 2008 were higher for $1.9^{\circ} \mathrm{C}$ and in 2009 for $1.8^{\circ} \mathrm{C}$.

Table 2. Average temperature $\left({ }^{\circ} \mathrm{C}\right)$ and precipitation $\left(1 / \mathrm{m}^{2}\right)$ for Banja Luka in 2007, 2008 and 2009

\begin{tabular}{|c|c|c|c|c|c|c|c|c|c|c|c|c|c|c|}
\hline \multirow[b]{2}{*}{ Year } & \multirow{2}{*}{$\begin{array}{l}\text { Temperature/ } \\
\text { precipitation }\end{array}$} & \multicolumn{12}{|c|}{ Month } & \multirow{2}{*}{\begin{tabular}{|c} 
Average \\
per year/ \\
Total per \\
year
\end{tabular}} \\
\hline & & I & II & III & IV & V & VI & VII & VIII & IX & $\mathrm{X}$ & XI & XII & \\
\hline \multirow{2}{*}{2007} & $\begin{array}{c}\text { Temperature } \\
(\mathrm{C})\end{array}$ & 6.2 & 7.1 & 9.2 & 13.8 & $18 . .3$ & 22.7 & 24.0 & 22.5 & 14.8 & 9.9 & 4.3 & 0.6 & 12.8 \\
\hline & \begin{tabular}{|c|} 
Precipitation \\
$\left(\mathrm{l} / \mathrm{m}^{2}\right)$
\end{tabular} & 65.6 & 71.3 & 95.6 & 4.5 & 95.0 & 81.0 & 38.2 & 60.9 & 154.5 & 146.2 & 127.6 & 99.3 & $1,039.7$ \\
\hline \multirow{2}{*}{2008} & \begin{tabular}{|c|} 
Temperature \\
(C)
\end{tabular} & 2.3 & 5.4 & 7.9 & 12.6 & 17.6 & 21.5 & 22.4 & 21.9 & 15.6 & 13.6 & 8.0 & 4.4 & 12.8 \\
\hline & \begin{tabular}{|c|} 
Precipitation \\
$\left(\mathrm{l} / \mathrm{m}^{2}\right)$
\end{tabular} & 39.2 & 12.3 & 157.7 & 102.9 & 70.9 & 79.6 & 85.2 & 24.3 & 106.7 & 69.3 & 77.7 & 66.0 & 891.8 \\
\hline \multirow{2}{*}{2009} & $\begin{array}{c}\text { Temperature } \\
(\mathrm{C})\end{array}$ & -0.7 & 2.7 & 7.6 & 14.2 & 18.9 & 20.0 & 23.3 & 22.8 & 18.6 & 11.4 & 8.7 & 4.6 & 12.7 \\
\hline & \begin{tabular}{|c|} 
Precipitation \\
$\left(\mathrm{l} / \mathrm{m}^{2}\right)$
\end{tabular} & 72.7 & 51.1 & 71.0 & 40.0 & 48.7 & 152.9 & 43.4 & 138.2 & 32.9 & 72.5 & 82.2 & 180.4 & 986.0 \\
\hline \multirow{2}{*}{$\begin{array}{l}1961- \\
2004\end{array}$} & $\begin{array}{c}\text { Temperature } \\
(\mathrm{C})\end{array}$ & -0.2 & 2.0 & 6.5 & 10.9 & 15.9 & 19.4 & 20.9 & 20.6 & 16.1 & 11.1 & 6.1 & 1.2 & 10.9 \\
\hline & \begin{tabular}{|c|} 
Precipitation \\
$\left(\mathrm{l} / \mathrm{m}^{2}\right)$
\end{tabular} & 71.3 & 62.9 & 77.5 & 90.9 & 95.4 & 111.6 & 94.5 & 82.8 & 94.3 & 80.5 & 98.2 & 89.3 & $1,047.0$ \\
\hline
\end{tabular}

In the period of global warming, the precipitation in Banja Luka region has been the most common limiting factor of successful agricultural production including production of fodder crops in arable land and grassland. Based on precipitation data (Table 2), it can be noticed that total sum per year of precipitation during all three years of examination (2007-2009) was smaller than many years average. Quantity of precipitation during vegetation period (AprilOctober) in 2007-2009 was significantly lower than many-year precipitation average. During examination in vegetation period of perennial ryegrass the lowest sum of precipitation was recorded in $2007\left(434.1 \mathrm{l} / \mathrm{m}^{2}\right)$.

\section{RESULTS}

Highly significant differences among autochthonous populations and variety Maya for all phenological traits were determined (Tables 3 and 4). This creates the possibility of an effective choice of progenies for their inclusion in the breeding germplasm and the creation of local varieties, suitable for different ways of forage production (pure sowing or mixtures) and utilization (for grazing, mowing/ grazing or grazing/mowing), or for the establishment of grasslands for special purposes (for sports and recreation grounds, for the protection and preservation of the environment, etc). 
The three-year average values of individual phenological phases in the examined autochthonous populations of perennial ryegrass and cultivar Maya are shown in Table 3. and Figure 1-5.

With a three year monitoring of growth of generative shoots, (GRGS) at the examined populations of perennial ryegrass a statistically significant difference between the populations was found, but also in relation to the variety of Maya. The GRGS was the lowest in the population Laminci (8.4 days), at the latest at Manjaca population (23.3 days). Interval of variation of this trait in population collection was 14,9 days, what was more than average value of populations (14.5).

Table 3. Phenological traits of perennial ryegrass population and cultivar (average values)

\begin{tabular}{|c|c|c|c|c|c|}
\hline Populations & GRGS & VEGF & IHF & FLOW & VEG \\
\hline Dragočaj & 19.3 & 40.8 & 9.8 & 15.4 & 95.4 \\
\hline Kosjerovo & 14.7 & 33.2 & 11.7 & 17.4 & 89.3 \\
\hline Laminci & 8.4 & 29.0 & 12.2 & 19.7 & 82.5 \\
\hline TAS & 11.8 & 30.7 & 11.9 & 19.4 & 87.2 \\
\hline Kupres & 14.2 & 32.9 & 11.3 & 19.8 & 84.3 \\
\hline Maglajani & 9.8 & 33.6 & 10.8 & 20.7 & 84.0 \\
\hline Manjača & 23.3 & 44.9 & 7.7 & 16.1 & 95.9 \\
\hline $\bar{X}$ of populations & 14.5 & 35.0 & 10.8 & 18.3 & 88.4 \\
\hline Variety Maya & 17.6 & 36.3 & 10.5 & 19.1 & 89.1 \\
\hline $\begin{array}{rr}\text { LSD } & 0,05 \\
& 0,01\end{array}$ & $\begin{array}{l}1.4 \\
1.8\end{array}$ & $\begin{array}{l}1.4 \\
1.8\end{array}$ & $\begin{array}{l}1.0 \\
1.3\end{array}$ & $\begin{array}{l}1.2 \\
1.5\end{array}$ & $\begin{array}{l}1.7 \\
2.2\end{array}$ \\
\hline
\end{tabular}

*Source: authors' elaboration based on original data

Vegetative phase finishes with the beginning of perennial ryegrass tillering and cutting of forage and it is one of the most important traits because it affects time of utilization and therefore the quality of produced biomass. The average VEGF in population collection was 35.0 days, and the differences between individual populations and cultivar Maya were statistically significant. This phase had the longest duration for populations Manjača and Dragočaj what refers them in late maturity genotypes. Population Dragočaj showed most stabile VEGF in all three trial years (Fig.2).

According to the results of three-year research, the average number of days from heading to starting of flowering (IHF) was 10.8 days, and the differences between tested populations were statistically highly significant (Table 3, Fig. 3). In population Manjača, this phase was the shortest (7.7 days). In contrast, the maximum IHF was found in population Laminci (12.2 days). 


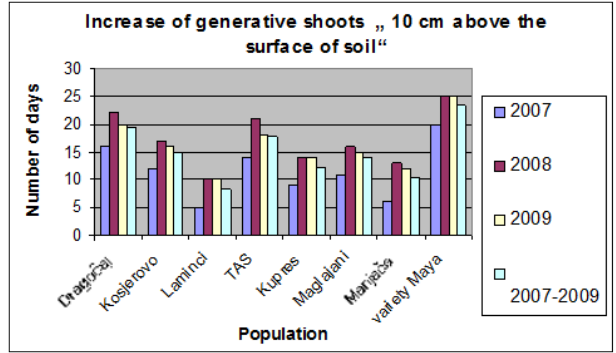

Figure 1. Increase of generative shoots „10 $\mathrm{cm}$ above

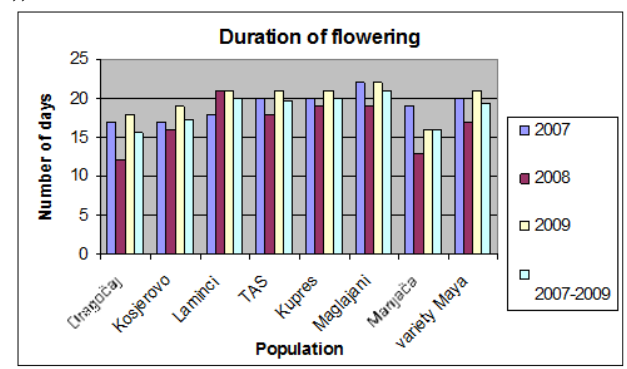

Figure 3. Interval of heading start of flowering

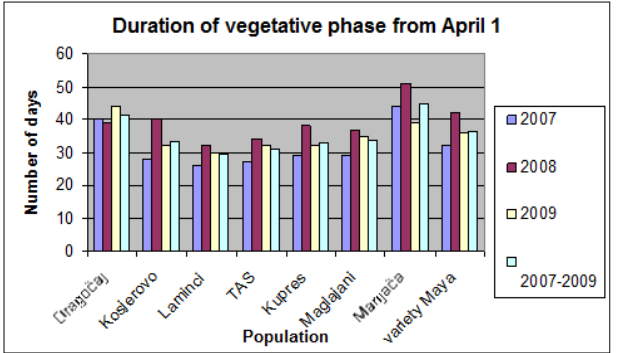

Figure 2. Duration of the surface of soil“vegetative phase from April 1

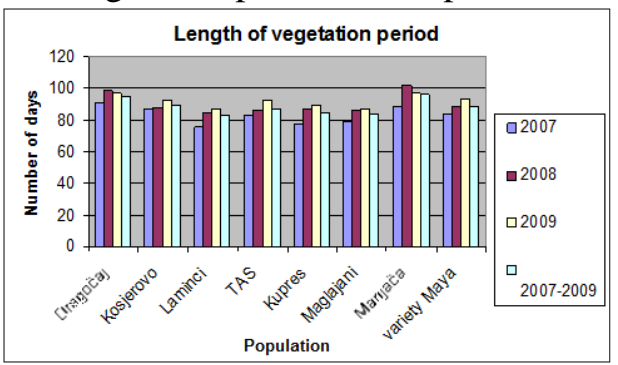

Figure 4. Duration of flowering

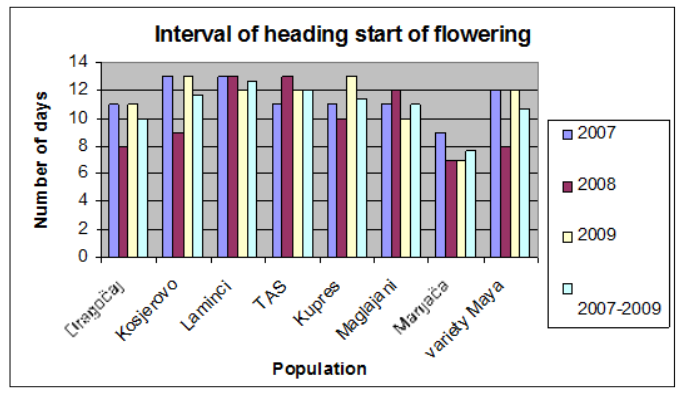

Figure 5. Length of vegetation period

The longest period of flowering (FLOW) was registered in the third, and the shortest one in the second year of study (Fig. 4). During the three-year research phenological phases of flowering lasted the longest in the population Maglajani (20.7 days) and shortest in the population Dragočaj (15.4 days). In relation to the variety Maya, four populations had longer FLOW (TAS, Laminci, Kupres and Maglajani).

The shortest average vegetation period (VEG) was found in populations Laminci (82.5 days) and Maglajani (84 days). In contrast, the longest VEG was determined in populations Manjača (95,9 days) and Dragočaj (95,4 days). Populations Dragočaj and Manjača had 7 days longer average VEG than cultivar Maya. The greatest variation in the duration of this phase observed by years, were registered on populations Kupres and Manjača (13 days), and the least in population Kosjerovo (6 days). 
Table 4. ANOVA and indicators of variability of observed properties

\begin{tabular}{|l|c|c|c|c|c|}
\hline \multicolumn{1}{|c|}{$\begin{array}{l}\text { Properties } \\
\text { Indicators } \\
\text { of variability }\end{array}$} & GRGS & VEGF & IHF & FLOW & VEG \\
\hline MS genotype & $299.90^{* *}$ & $340.08^{* *}$ & $25.49^{* *}$ & $43.35^{* *}$ & $307.07^{* *}$ \\
\hline MS year & $291.89^{* *}$ & $414.07^{* *}$ & $18.82^{*}$ & $75.78^{* *}$ & $716.07^{* *}$ \\
\hline MS interaction & $1.60^{\text {ns }}$ & $33,75^{* *}$ & $7.95^{* *}$ & $8.86^{* *}$ & $26.16^{* *}$ \\
\hline $\begin{array}{l}\text { Genetic } \\
\text { variance } \sigma_{\mathrm{g}}^{2}\end{array}$ & 299.45 & 330.44 & 23.22 & 40.82 & 299.60 \\
\hline $\begin{array}{l}\text { Phenotype } \\
\text { variance } \sigma_{\mathrm{f}}{ }_{\mathrm{f}}\end{array}$ & 303.05 & 349.84 & 28.94 & 47.89 & 317.02 \\
\hline $\begin{array}{l}\text { Heritability } \mathrm{h}^{2} \\
(\%)\end{array}$ & 98.81 & 94.45 & 80.25 & 85.24 & 94.50 \\
\hline
\end{tabular}

Based on the results of ANOVA, it was found that the influence of genotype and year to all phenological traits was highly significant (Table 4). Presence of highly significant interaction (genotype $\mathrm{x}$ year) was found for all phenological traits except for the growth of generative shoots $10 \mathrm{~cm}$ above the ground.

The share of genetic into phenotypic variance indicates that the variability of the duration of the explored phenological phases in this collection of populations is based dominantly on the plant genotypes. Heritability in a broad sense is high for all traits and it indicates also a large proportion of the genetic in total phenotype variability of researched properties.

For better success of breeding work it is necessary to understand the genetic origin, structure of genetic and phenotype variance, heritability, and the interdependence of functionally related properties. Therefore, correlations that suggest possible directions of changes of different properties of plant material under the influence of applied method of selection are of particular importance. All coefficient of correlations were highly statistically significant except correlation between VEG and IHF, which was only significant on p > 0,95 (Tab. $5)$.

Table 5. Coefficient of correlation of researched traits of perennial ryegrass populations

\begin{tabular}{|c|c|c|c|c|}
\hline Properties & VEGF & IHF & FLOW & VEG \\
\hline GRGS & $0.8553^{* *}$ & $-0.7154^{* *}$ & $-0.6546^{* *}$ & $0.8630^{* *}$ \\
\hline VEGF & & $-0.7198^{* *}$ & $-0.5834^{* *}$ & $0.7224^{* *}$ \\
\hline IHF & & & $0.6120^{* *}$ & $-0.4895^{*}$ \\
\hline FLOW & & & & $-0.5525^{* *}$ \\
\hline
\end{tabular}

$* \mathrm{p}>0,95 * * \mathrm{p}>0,99$ 


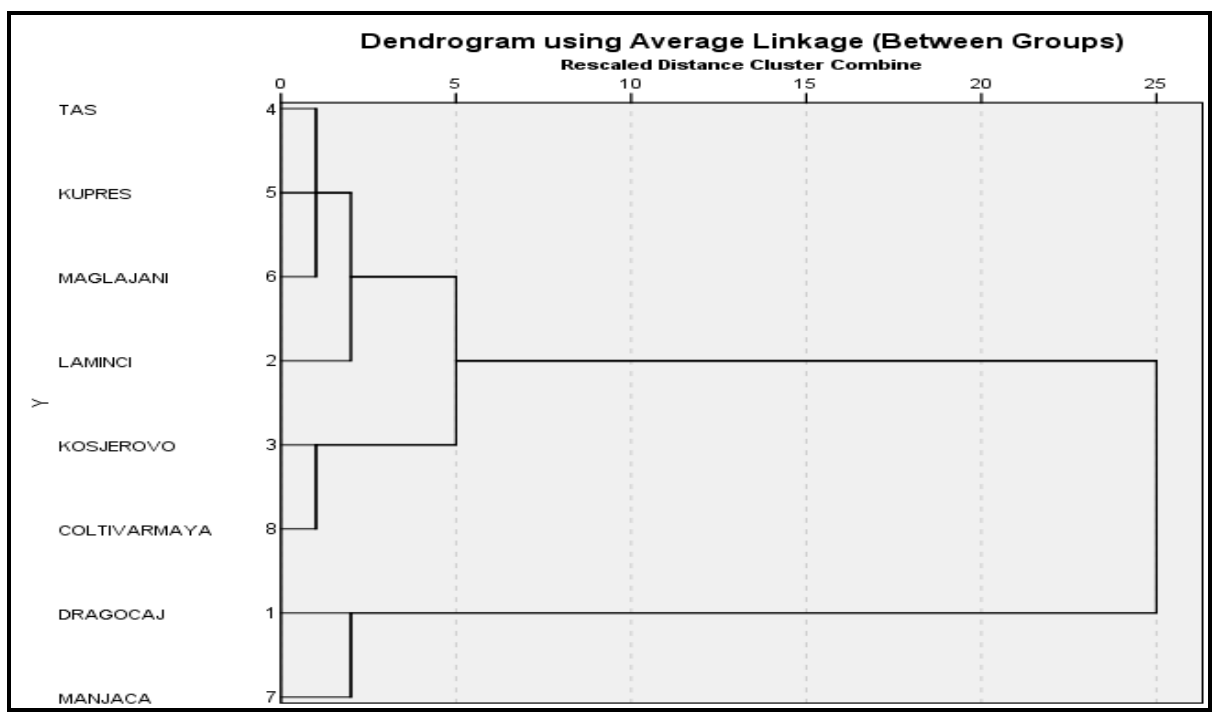

Figure 6. Cluster diagram of the studied populations of perennial ryegrass

On dendogram which was formed as a result of hierarchical cluster analysis (Fig. 6) two groups of populations can be observed. The first group is made up of two sub-groups. In the first subgroup are the following populations: TAS, Kupres, Maglajani and Laminci. The characteristic for this group is the longest period of flowering and the shortest length of vegetation. The second subgroup consists of the population Kosjerovo and variety Maya, and it is characterized by an intermediate maturity. The second group consists of the population Dragočaj and Manjača which are characterized by the latest maturity and the longest duration of the vegetation, short periods from heading to flowering and flowering per se.

\section{DISCUSSION}

By observing the date of appearance of generative shoots $10 \mathrm{~cm}$ above ground it was noticed that later emergence counting from April $1^{\text {st }}$ resulted in late heading stage. Whyte et al. (1975) stated that the varieties of perennial ryegrass mutually differed in earliness, and late maturing, and there were early, middle early, and medium late varieties, which is in accordance with the results of this research. Earliness is a very important property in the case of perennial ryegrass, which is characterized by the time of heading (Hemphreys, 1989).

During the three-year studies, the duration of the vegetative phase of the examined perennial ryegrass populations was 35 days. The average duration of the vegetative phase in the examined perennial ryegrass populations ranged from 29 to 45 days, so these results are consistent with the results quoted by Sokolovic et al. (2001), in which the vegetative phase of perennial ryegrass lasted from 39.8 to 65.2 days. According to Charmet and Balfourier (1994), the time of heading of European population is quite long, and lasts from 30 to 70 days. Surault et al. 
(2009) find that the date of heading of perennial ryegrass was very important for biomass production. These authors conducted the micro experiment in France examining 9 varieties of perennial ryegrass in pure sowing and 10 mixtures with different perennial ryegrass varieties, to determine an impact of date of heading to biomass yield. According to these authors, later maturity varieties achieved lower biomass yield as compared to the early and medium late varieties. Mixtures with two or three different varieties of perennial ryegrass with different time of heading had intermediate biomass yield and did not have higher yields than in pure sowing. Rossignol et al. (2014) found that the tested populations of three grass species depending on the current ripeness of population and phenological peak differed significantly in the amount of vegetative matter.

Based on the three-year results of research, the average length of the interval from the beginning of heading to the beginning of blossoming was 10.8 days. In the studied populations of perennial ryegrass interval of heading-start of blossoming in population Manjača was the shortes lasting for 8 days and in the population Laminci it was the longest lasting for 13 days, which is in compliance with the results of Sokolovic et al. (2001), which stated that the heading-start of blossoming period lasted from 8.6 to 19.5 days.

Blossoming of perennial ryegrass genotypes lasted 18.3 days on average, and blossoming interval was 16-21 days, indicating significant differences between populations. Phase of blossoming was the shortest in 2008, 17 days, or in other words blossoming of researched populations lasted from 12 to 21 days. In the 2009, the blossoming lasted 20 days on average, i.e. from 16 to 21 days. Martiniello (1998) pointed out that early blossoming of perennial ryegrass was an important property indicating the ability to increase seed yield. Namely, the populations of perennial ryegrass, which had previously blossomed, and whose interval of blossoming lasted longer could achieve a higher seed yields compared to the population in which the interval of blossoming was shorter. The perennial ryegrass varieties blossoming later have a higher proportion of green mass and smaller stems in area of grazing in relation to varieties that have intermediate blossoming (Stewart and Hayes, 2011). Blossoming time can significantly affect the dry weight of the leaves (Ansquer et al., 2009). During the research of a large number of indigenous populations of perennial ryegrass Lakic et al. (2013) determined the existence of a highly significant positive genetic correlation between the start of blossoming and spike length as well as the start of blossoming and mass of 1000 seeds.

During the three-year research, the average length of vegetative period of perennial ryegrass genotypes lasted 87 days. Length of vegetation period in 2007 lasted from 76 to 91 days, or 83 days on average, in the 2008 it was 90 days on average, or from 85 to 102 days, and in the 2009 it was from 87 to 97 days, or 92 days on average.

High values of heritability determined for some phenologic phases pointed to a great participation of genetic in a total phenotype variability of examined traits. Moderate heritability in jointing $\left(\mathrm{h}^{2}=0,72\right)$ revealed a large environmental 
impact. In contrast, high heritability $\left(\mathrm{h}^{2}=0,86\right)$ in heading, flowering and the critical phase implied a strong genetic effect (Ullmann et al., 2016).

\section{CONCLUSIONS}

One of the important phenological characteristics of perennial grasses, including ryegrass, is the emergence of the reproductive organs, i.e. emergence of beginning of ears in the stem at a height of $10 \mathrm{~cm}$ above ground. On the basis of this trait the maturing of grasses can be determined, as well as the optimum time for short-term utilization of grassland by grazing and no adverse impact on the further growth and development of plants, i.e. taking advantage by mowing. By observing this phase, it was noted that the populations in which there was a later appearance of generative shoots in the stem and the later start of heading, had a shorter blossoming period.

\section{ACKNOWLEDGEMENT}

This work was supported by the Program of preservation of plant genetic resources of the entity of Republic of Srpska $(\mathrm{BiH})$, carried out by Institute for genetic resources of University of Banja Luka.

\section{REFERENCES}

Ansquer P, Al Haj Khaled R,Cruz P, Theau JP, Therond O, Duru M (2009) Characterizing and predicting plant phenology in species-rich grasslands. Grass and Forage Science 64: 57-70.

Charmet G, Balfourier F (1994) Influence of ecological factors on population differentiation in perennial ryegrass (Lolium perenne L.). Genetic Resources and Crop Evolution 41: 175-184.

Grogan D, Gilliland TJ (2011) A rewiev of perennial raygrass variety evaluation in Ireland. Irish J Agric Food Res 50: 65-81.

Lakic Ž, Sokolovic D, Babic S, Vojin S, Ikanovic J, Veljovic T, Balalic I (2013) Genetic variabilyty of seed yield and seed components of autochthonous Lolium perenne L. populations. Genetika 45: 553-556.

Lakic Ž, Balalic I, Vojin S (2015) Interpretation of Genotype × Environment interaction in Perennial ryegrass (Lolium perenne L.). Genetika 47: 509-522.

Martiniello P (1998) Influence of agronomic factors on the relationship between forage production and seed yield in perennial forage grasses and legumes in a Mediterranean environment. Agronomie 18: 591-601.

Rossignol N, Andueza D, Carrère P, Cruz P, Duru M, Fiorelli JL, Michaud A, Plantureux

Sokolovic D, Tomic Z, Šurlan-Momirovic G (2001) Genetička vrijabilnost autohtonih populacija engleskog ljulja (Lolium perenne L.). Journal of Scientific Agricultural Research 62: 27-34.

Sokolovic D, Radovic J, Lugic Z, Tomic Z, Babic S (2006) Genetic variability of perennail ryegrass (Lolium perenne L.) autochthonous populations collected in Serbia for see yield and seed yield components. Proceedings of EUCARPIA fodder crops and amenity grasses section and Medicago spp. Group joint Meeting, Perugia, Italy, pp. 253-256.

Sokolovic D, Lugic Z, Radovic J, Zivanovic T, Babic S, Simic A, Miletic R (2011) Evaluation of morphological traits, dry matter yield and quality of Lolium perenne L. autochthonous populations from Serbia through multivariate analysis.Genetika 43:129 -140. 
Stewart A, Hayes R (2011) Ryegrass breeding - balancing trait priorities. Irish Journal of Agricultural and Food Research 50: 31-46.

Surault F, Julier B, Veron R, Huyghe Ch (2009) Forageproduction of grasslands composed by one, tvo or three varieties of perennial ryegrass. XVIIIth Meeting of the Eucarpia Fodder Crops and Amenity Grasses Section, Book of Apstracts, La Rochelle, France, p. 62.

Ullmann I, Herrmann A, Hasler M, Cai D (2016) Variability in the critical phase of stem elongation of perennial ryegrass genotypes: a source for breeding progress? Jurnal of Agricultural Science 154: 1002-1014.

Whyte RO, Moir TRG, Cooper JP (1975) Grasses in Agriculture. FAO Agricultural Studies, Food and Agriculture Organisation of the United Nations, Italy, p. 417.

Yamada T (2013) Perennial ryegrass. In: Genetics, genomics and breeding of forage crops. (Eds. H Cai, T Jamada, C Cole). CRC Press, Boca Raton, Florida, USA, pp:11-35. 